\title{
Hemispheric and Transborder Perspectives: Racialization of Mexicans through Time ${ }^{1}$ \\ Lynn Stephen \\ University of Oregon
}

This article embeds a discussion of contemporary transborder communitiescommunities spread out in multiple locations in the U.S. and Mexico-in the history of U.S.-Mexico relations as seen through the colonial and contemporary mapping of space, place, people, race, and ethnicity both visually through the creation of maps and then metaphorically through U.S. immigration policy in the $19^{\text {th }}$ and $20^{\text {th }}$ centuries. I argue that the concept of "transborder" which can include borders of coloniality, ethnicity, race, nation, and region can help us to illuminate U.S.-Mexico relationships through time and the complexities of the racialization of Mexicans in the U.S.

Lynn Stephen received her doctorate from Brandeis University. She is currently a Distinguished Professor of Arts and Sciences, Professor of Anthropology, and Director of the Center for Latino/a and Latin American Studies (CLLAS) at the University of Oregon. She has also recently served as co-coordinator (20092011) for University of Oregon initiative "The Americas in a Globalized World: Linking Diversity and Internationalization." Her work has centered on the intersection of culture and politics. Born in Chicago, Illinois she has a particular interest in the ways that political identities articulate with ethnicity, gender, class, and nationalism in relation to local, regional, and national histories, cultural politics, and systems of governance in Latin America and the U.S. During the past fifteen years she has also engaged the themes of immigration, human rights, neoliberal political-economies, collaborative ethnography, and social movements in her research. She has conducted research in Mexico, El Salvador, Chile, Brazil, and the U.S.

\section{Introduction: From Friendship Park to a 600 Mile Wall}

Friendship Park is a part of Border Field State Park in San Diego, formally established in 1974. It's a place where families have united across the border to talk, husbands and wives met for weekly chats, and cross-border cultural and political exchanges took place-in many cases across a chain-link fence or on the beach. Now friendship is being replaced with concrete. Federal contractors are installing triple fencing along the final three and a half miles of the boundary between San Diego and Tijuana. They're filling canyons with dirt and bulldozing land along the border to put in a high-speed access road. The perceived purpose of the 600 mile wall being built by the U.S. government on the U.S.-Mexico 
border at a cost of 3.2 billion to construct and 6.5 billion to maintain is to keep people out (Government Accountability Office). ${ }^{2}$ While the virtual part of the wall calling for the construction of a series of surveillance towers with high tech surveillance equipment (cameras and sensors) was stopped by the Obama administration in March of 2010 (Hsu, "Work to Cease"), the construction of physical walls in many places is ongoing as is the militarization of the U.S.Mexico border. In May of 2010, President Obama called for the deployment of 1,200 National Guard Troops to join the 340 who are already posted on the border (Shear and Hsu). In U.S. politics, national discussions about "border security," remain focused on the concept of a "wall,"--both physical and military.

The Berlin wall, which fell in 1989, was to keep people in. Ironically, U.S. border policy since 1996 under the Clinton administration has functioned as much to keep people here as to keep them out. U.S. policy of tighter border enforcement has "lengthened U.S. sojourns of unauthorized migrants and increased their probability of settling permanently in the United States. In 1992, about 20 percent of Mexico to U.S. migrants returned home after six months... and by 2000 , only 7 percent did so" (Cornelius 5 ). ${ }^{3}$ It has also literally killed people. Since President Clinton initiated Operation Gatekeeper in San Diego in 1994 which was the first of many smaller walls constructed on the border, more than 5,600 people have died crossing the border according to a study released by the American Civil Liberties Union of San Diego and Imperial Counties and Mexico's National Commission on Human Rights (CNDH) (Jiménez). These numbers do not include the disappeared whose numbers may exceed those found dead (Stephen, "Nuevos Desaparecidos"). It has also facilitated the growth of the multi-billion dollar human smuggling business, which is now significantly controlled by and integrated with the drug business spanning the broader territories of Mexico and the U.S (Meyer). A 2010 U.S.-Mexican government study found that between $\$ 19$ and $\$ 29$ billion dollars a year in cash is shipped by drug cartels from the U.S. to Mexico and laundered through cash purchases of land, luxury hotels, expensive cars, and other items, eluding detection. This is estimated to be more than half, but not all of the profits earned 
in the U.S. by drug sales (Wilkinson). How did we go from a "friendship park" built in the 1970s to a triple wall which is keeping people here, killing people, and facilitating the drug business in the U.S? How does "the wall" concept keep us from understanding the shifting and multiple borders people cross through time? Can a transborder approach help us to develop a historical understanding of U.S.-Mexican relations that might inform our understanding of the racialization of Mexicans in the U.S. today?

This article embeds a discussion of contemporary transborder communities-communities spread out in multiple locations in the U.S. and Mexico-in the history of U.S.-Mexico relations as seen through the colonial and contemporary mapping of space, place, race, and ethnicity both visually through the creation of maps and then metaphorically through U.S. immigration policy in the $19^{\text {th }}$ and $20^{\text {th }}$ centuries. I argue that the concept of "transborder" which can include borders of coloniality, ethnicity, race, nation, and region can help us to illuminate U.S.-Mexico relationships through time, the complexities of the racialization of Mexicans in the U.S., and contemporary dynamics of migration and immigration. The crossing of many borders and the carrying of these borders within one's experience allows us to see migration and immigration in terms of family relationships, social, economic, and cultural relationships, communities, and networks beyond the legal relations that individuals have with nation states and the physical border between the U.S. and Mexico.

\section{Moving Borders in History: Mapping Space, Place, Race, and Ethnicity}

Most people today envision the border where it was settled in 1848 with the signing of the Treaty of Guadalupe Hidalgo and then the additional lands that came through the Gadsden Purchase of 1853. But where was the U.S.-Mexican border prior to that? If we look at some early maps of the Americas we see no borders we recognize. 


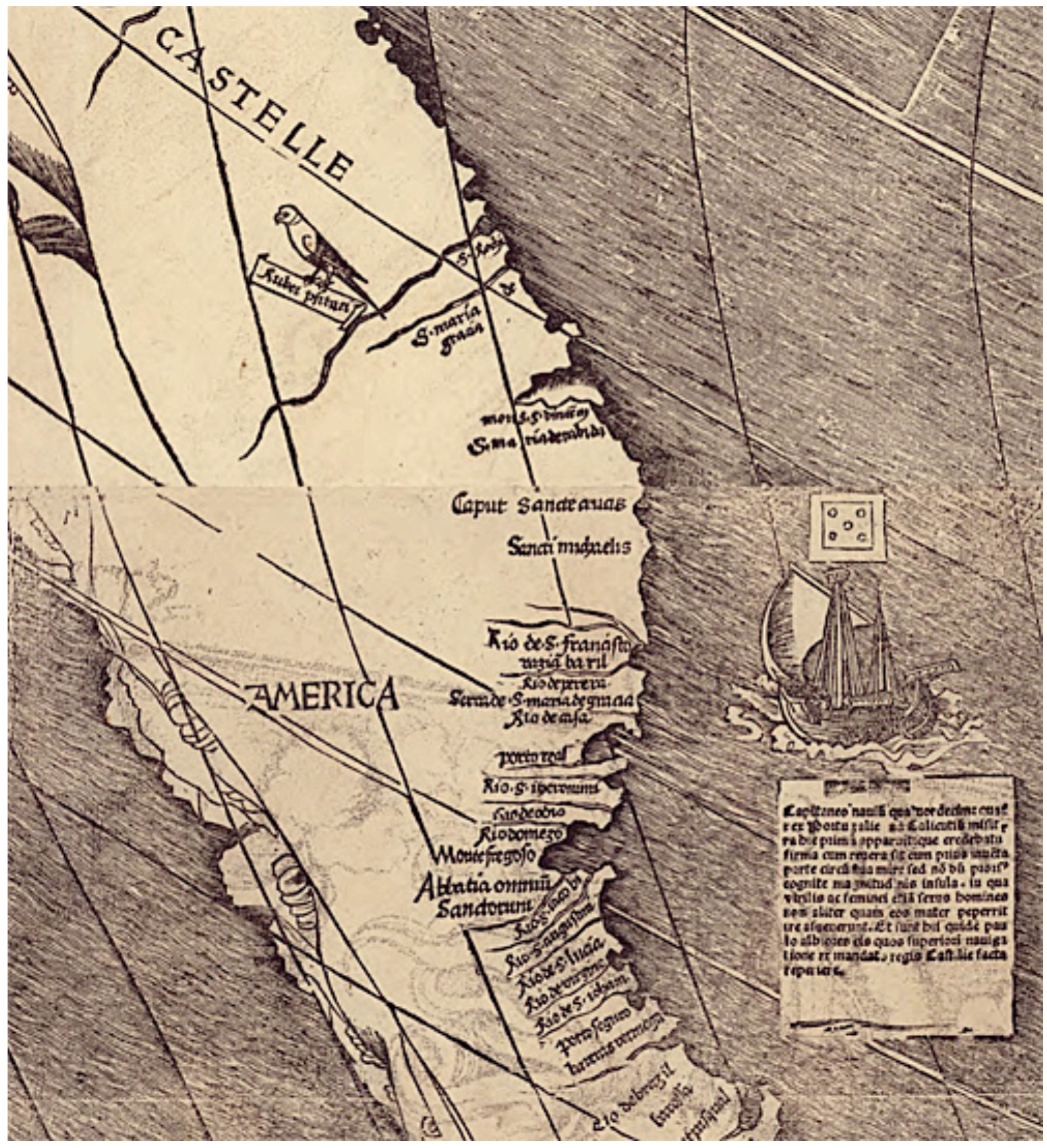

Figure 1. Martin Waldseemüller, "Map with America, 1507," map, http://commons.wikimedia.org/wiki/File:Waldseemuller map closeup with Ameri ca.jpg

The map above, printed in 1507, is the first world map in which the name "America" appears for the lands of the New World. The compiler of the map, Martin Waldseemüller (1474-1519), was a German-born priest and cartographer. Many people suspect that it was this map that caused the hemisphere to be called "America," after explorer Amerigo Verspucci. While contemporary Latin 
Americans are quick to claim an identity as "Americanos" and as living in America, many people in the U.S. today are puzzled when others outside the U.S. want to call themselves "Americans" as well. Thinking from the position of the hemisphere and extending the definition of who is "American" as this 1507 map suggests, requires us to suspend our current notions of borders.

We must also recognize this map, however, as a basic element of European colonialism. "America" as imagined in Europe is very different from the mapping, which indigenous peoples did of those around them and with whom they interacted. In fact, indigenous maps from the early colonial period reflect a very different conceptualization of the relationships between place, people, and landscape than European maps.

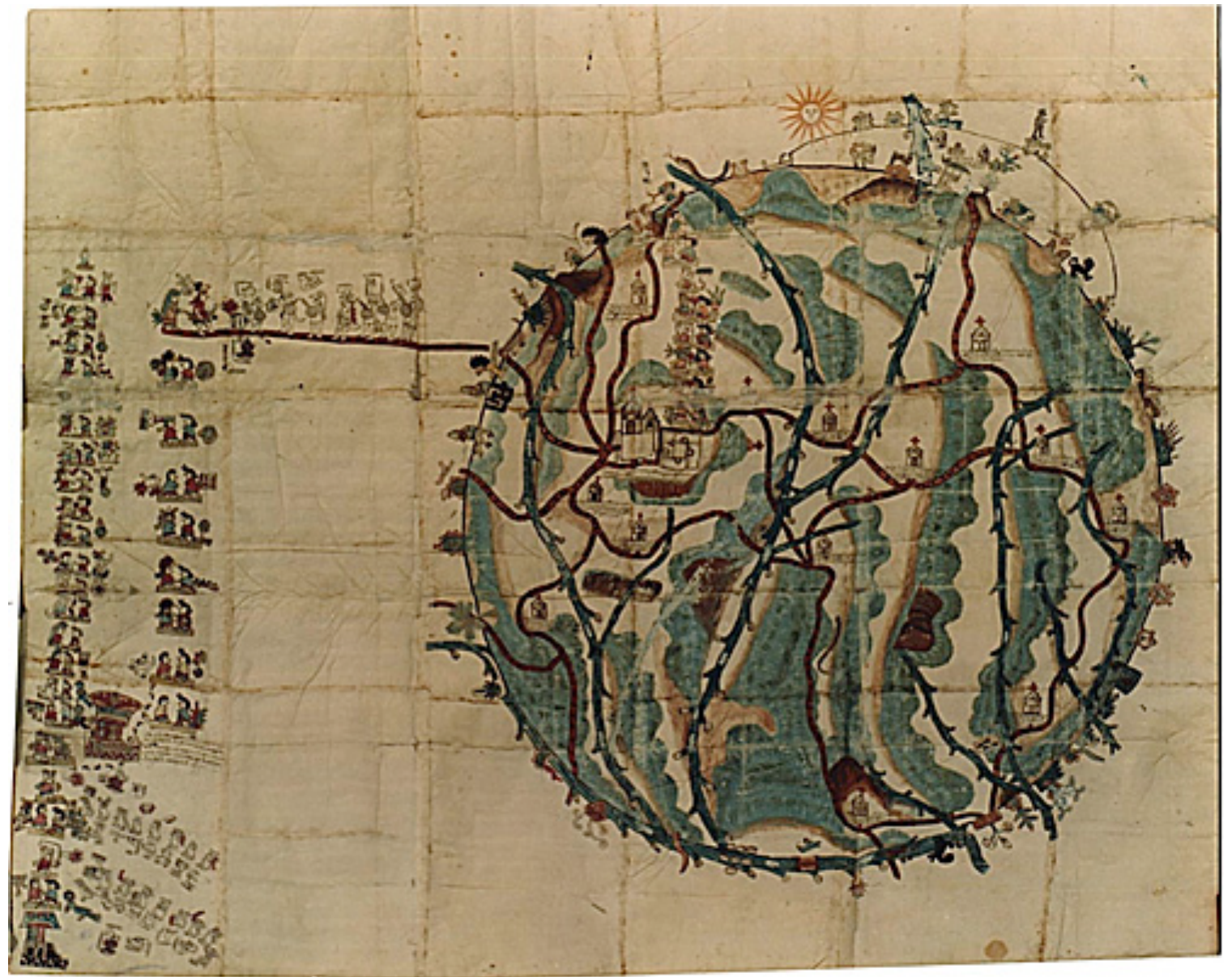

Figure 2. Relaciones Geográficas Collection, "Teazocoalco," map, Nettie Lee Benson Latin American Collection, http://www.lib.utexas.edu/benson/rg/rg images4.html Used by permission of the Nettie Lee Benson Latin American Collection, University of Texas, Austin 
The map above, of Teozacualco, today known as San Pedro Teozacualco, in the Mixtec region of Oaxaca, Mexico was created in 1580 in response to a project sponsored by King Phillip II of Spain known as the Relaciones geográficas. The project entailed questionnaires sent around to towns and asked them to respond to fifty questions. Question number ten asked the respondents to describe "the site and location of the said town, if it is situated high or low on a plain, with a picture of the layout and a design of the streets and plazas and other places indicated, including monasteries, as well as can be sketched on a map declaring which part of the town faces north and south" (Terraciono 21). The map of Teozacualco was drawn in response to this question, but represents a very different idea of "mapping" than was perhaps in the minds of those who wrote the instructions.

Constructed in the form of a circle, this map uses a radial concept to illustrate 14 churches, a network of roads, rivers, hills, valleys and other natural features, the socio-political organization of Teozacualco in relation to 13 other communities, boundaries with other political jurisdictions, and genealogies. The genealogies are of the hereditary rulers from Teozacoalco and neighboring Tilantongo with the male and female rulers of each couple seated together on a woven reed map, representing a dynastic marriage. The map has script and names in Spanish and Mixtec. Like other Mixtec maps, this one links place names, stories of place founders, and genealogies to landscape and cosmology. There is not a separation between human stories and place stories and the earth. In a detailed analysis of this map, ethnohistorian Kevin Terraciano writes of the pictoral artists who created the map:

They did not think of "maps and genealogies" as discrete categories, as did Europeans of the early modern period. The map's vertical alignment of ruling couples, the men and women who represented numerous people and places, associated the landscape with centuries of human occupation and history, combining representation of space and time in the same composition. The prominence of place-names and human figures of the 
"mapa" invokes the Ñudzahui (Mixtec) term for "world," ñuu-ñayehuiliterally "communities" of "places" (ñuu) and "people" (ñayehui). From a local point of view, this map represents Teozacualco's world" (24).

This map can make us conscious of the fact that even under Spanish colonialism, other forms of representation of local and regional worlds co-existed than the kinds of categories, relationships, and divisions expressed in European maps and thinking. In our analysis, contrasting the 1580 Mixtec map of Teozacualco with later maps of colonial Mexico, we can conceptually see how the borders of coloniality are incorporated into map-making but also resisted in the continued mental mapping by indigenous peoples of their local landscapes. This is a point I will return to later in discussing how we conceptualize transborder communities.

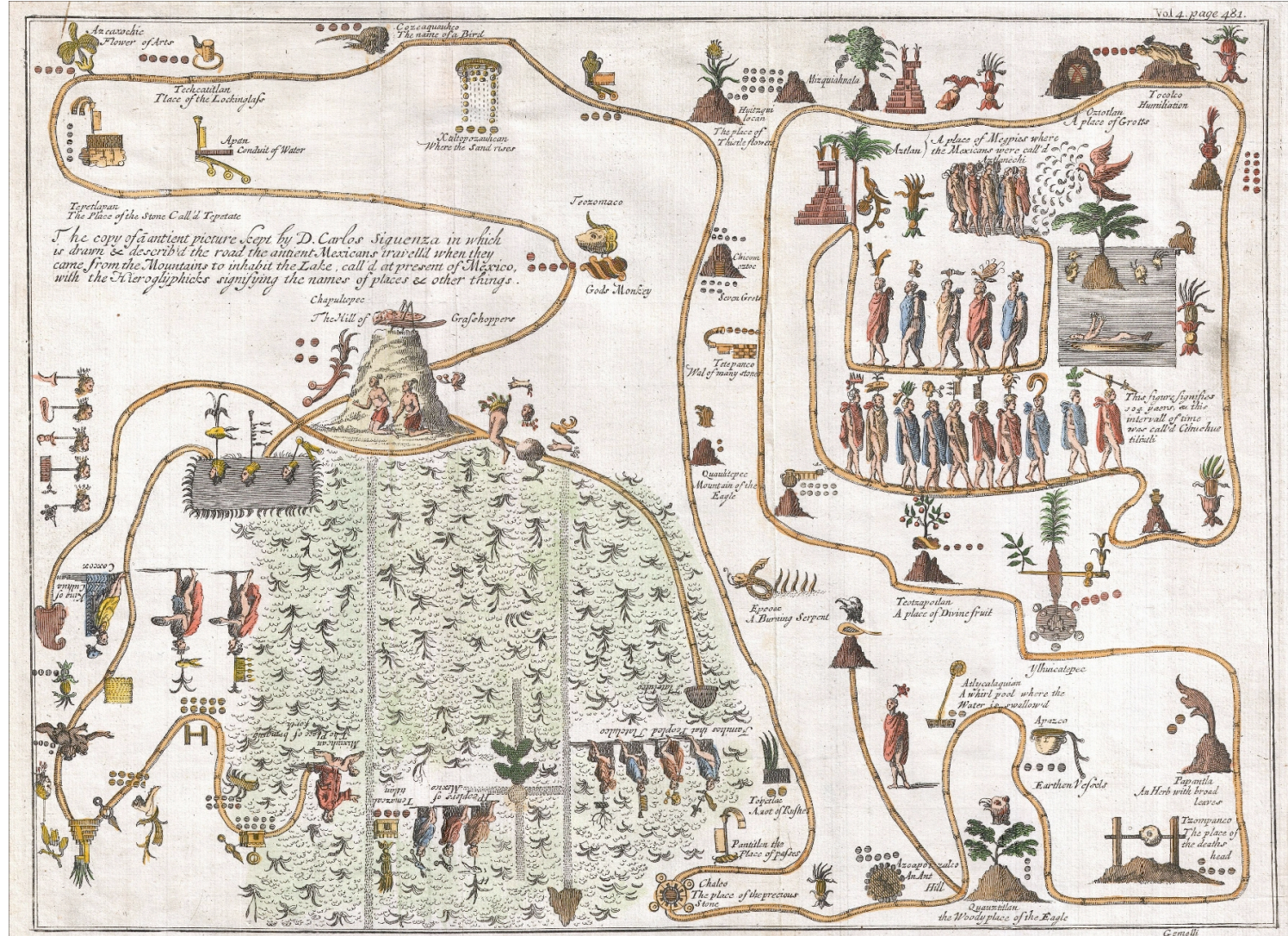

Figure 3. Map drawn by Giuvanni Francesco Gemelli Careri of Aztec Migration from Aztlan to Chapultapec from "Voyage Round the World", 1704. Image is in the public domain because its copyright has expired. http://en.wikipedia.org/wiki/File:Gemelli_Careri_Aztec_Map.jpg 
This 1704 map drawn by Giuvanni Francesco Gemelli Careri, is the first published representation of the legendary Aztec migration from Aztlán to Chapultepec Hill, currently Mexico City. The map is supposed to be copied from indigenous sources. It traces the pilgrimage conceptually and features cartographic and spiritual elements with labels in Nahuatl and loose English translations. On May 24, $1065 \mathrm{CE}$, the Mexica (Aztec) began an epic migration from their ancestral homeland, Aztlan, which translated means "Place of Reeds" or "Place of Egrets", to the shores of Lake Texcoco, in Mexico's Central Mesa. There they founded the city of Tenochtitlán. This map offers a valuable conversation point for linking colonialism and Chicano Studies through the concept of Aztlán across borders. Like the Mixtec map of Teozacualco, it links genealogies to place and counterposes representations of space and time in the same document. While both of the Aztlán and Teozacualco maps were produced during the colonial period, we might also recognize that the relevant borders for indigenous peoples before the 1519 Spanish conquest were quite different from those we associate with Mexico now.

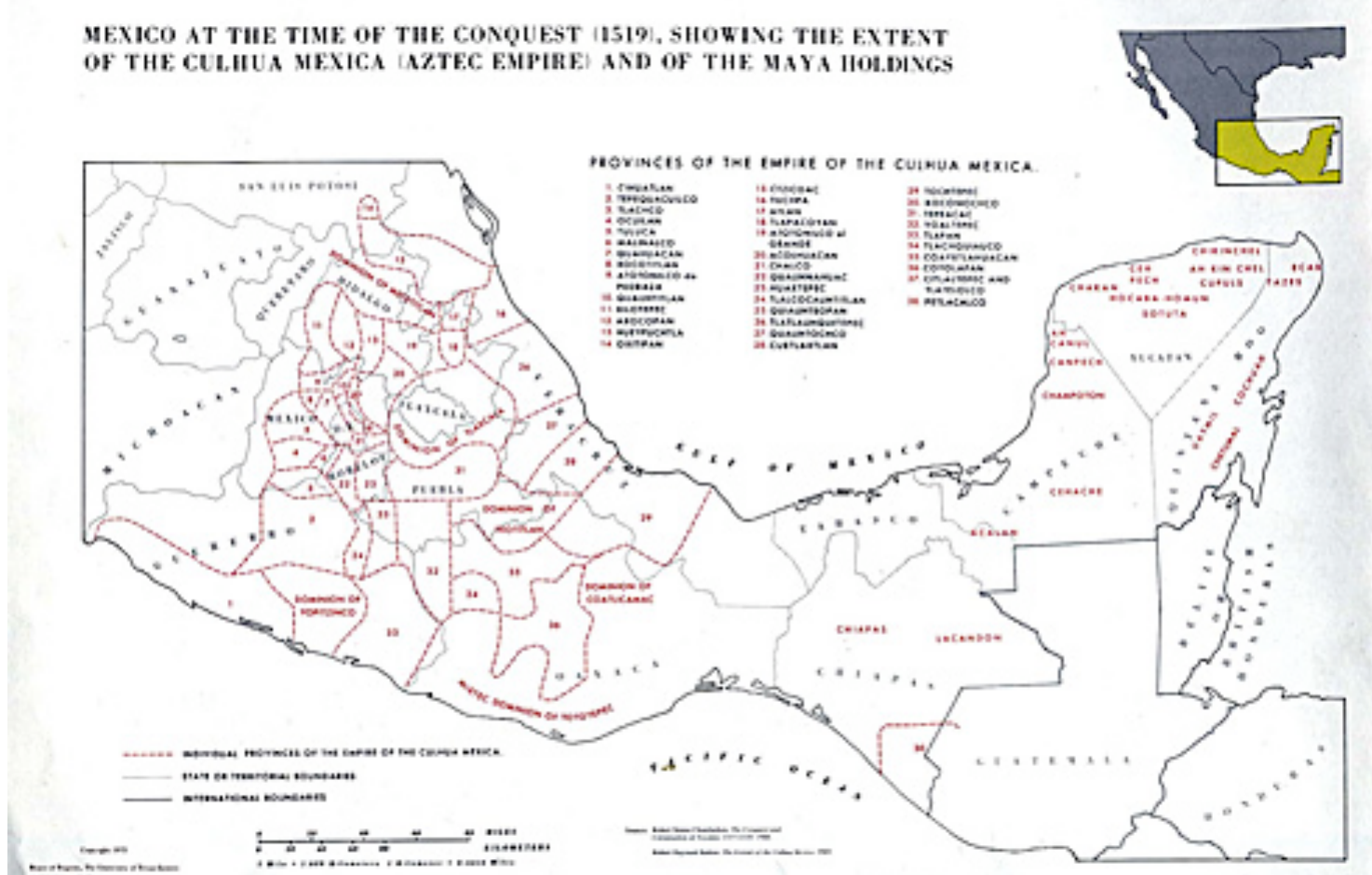

Figure 4. Stanley Alan Arbingast, "Mexico at the Time of the Conquest, 1915," map, in Atlas of Mexico (Austin, 1975), 24. Used by permission of the University of Texas Libraries, University of Texas, Austin. 
The map above shows the provinces of the Empire of the Culhua Mexico. While published in 1975 from a modern perspective, this map allows us to imagine other geographical and cultural boundaries of significance before 1519 . Spain's assertion of territory in "America" created a layer of borders through the process of colonialism, which I will argue still permeates the experiences of people in transborder communities today. Borders of coloniality, beginning in the 1500s, are built into historical and contemporary constructions of race, ethnicity, and belonging in both the U.S. and Mexico. As we begin to see the mapping of the continent of America filled in with colonial markers, boundaries, categories, and names we can also observe the unfolding of racial and ethnic hierarchies tied to local, regional, and eventually national histories. 


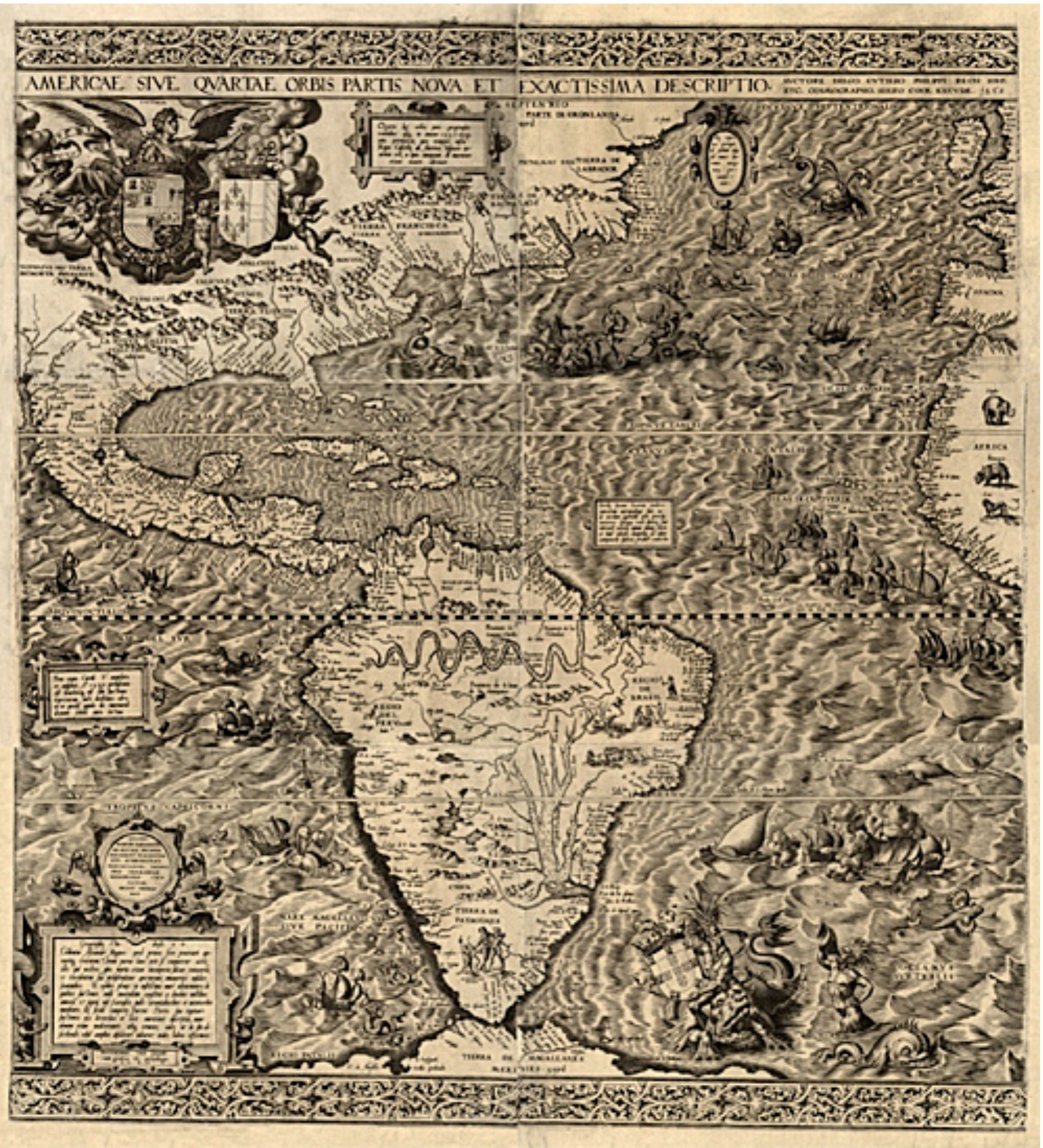

Figure 5. Diego Gutiérrez and Hieronymus Cock, "Americae sive quartae orbis partis nova et exactissima description, 1562" ("The Americas, or A New and Precise Description of the Fourth Part of the World, 1562"), http://commons.wikimedia.org/wiki/File:1562 Americæ Gutiérrez.JPG Used by permission of the U.S. Library of Congress

This 1562 map above of "Americae" by Diego Gutiérrez and Hieronymus Cock was published in 1562 by the Casa de Contratación in Seville--the central authority for Spanish travel to America and custodian of charts and sailing directions. This map suggests concrete place claims and administrative units 
created by Spain such as "Tierra de Patagonia," "Regio de Brasil," "Regio de Peru," "Tierra Florida," "California," and "Nuevo España." The different place names and administrative units on the map provide a detailed sense of region and differentiated locations, suggesting the possibility of many different types of borders—but all still within a continent labeled as "Americae."



Figure 6. Stanley Alan Arbingast, "The Viceroyalty of New Spain, 1786-1821," map, in Atlas of Mexico (Austin, 1975), 26. Used by permission of the University of Texas, Austin

A map of the Viceroyalty of New Spain from 1786 through 1821 provides more familiar outlines of the U.S. as a growing empire perched to absorb the territory of New Spain as its own territory expands westward. This map provides a picture of U.S. empire-building which in many ways resembles that of a colonial power-vis-à-vis New Spain. Here, "America" is not claimed as a hemispheric label but as part of "The United States of America," forming the pivot point for U.S. nationalism and claims to further territory. In addition to the "United States of 
America," we see "The Louisiana Purchase," a series of "intendencies" inside of New Spain's boundaries which signal future states in independent Mexico and in the territories that the U.S. will usurp from Mexico in 1848. The Province of Texas, the Government of New Mexico, and the Government of New California all portend contested territories. The Vice-Royalty of New Spain spanned from north of the Great Salt Lake including the government of New California, the Government of New Mexico, and the provinces of Texas, Coahuila, and Nuevo Santender which all occupied territory that the U.S. took from Mexico in 1848. Mexico became independent of Spain in 1821.

In Texas, Spain and then Mexico used land grants to encourage Hispanic and Anglo settlement. By the 1830s, Texas contained 25,000 Anglos and 4,000 Spanish-speaking Mexicans. In the 1830s, Mexico abolished slavery and passed the Colonization Law to prevent slaves from being imported into Texas by Anglo landowners. Anglo settlers revolted and created the Republic of Texas in 1836. Mexico never recognized the independence of Texas and broke off diplomatic relations with the U.S. when it admitted Texas as a state in 1845. The U.S. government tried to purchase areas of New Mexico and California from Mexico, which Mexico refused.

In the summer of 1845, John O'Sullivan, editor of the Democratic Review, published an essay titled "Annexation" which urged the U.S. to admit Texas as a state to the union. In that essay, O'Sullivan coined the famous saying "manifest destiny," urging not only the end to opposition to the annexation of Texas, but also forecasting Mexico's justifiable loss of California as well to the U.S.

Why, were other reasoning wanting, in favor of now elevating this question of the reception of Texas into the Union, out of the lower region of our past party dissensions, up to its proper level of a high and broad nationality, it surely is to be found, found abundantly, in the manner in which other nations have undertaken to intrude themselves into it, between us and the proper parties to the case, in a spirit of hostile interference against us, for the avowed object of thwarting our policy and hampering our power, limiting our greatness and checking the fulfillment of our manifest destiny 
to overspread the continent allotted by Providence for the free development of our yearly multiplying millions....

...California probably, next fall away from the loose adhesion which, in such a country as Mexico, holds a remote province in a slight equivocal kind of dependence on the metropolis. Imbecile and distracted, Mexico never can exert any real governmental authority over such a country. The impotence of the one and the distance of the other, must make the relation one of virtual independence; unless, by stunting the province of all natural growth, and forbidding that immigration which can alone develop its capabilities and fulfill the purposes of its creation, tyranny may retain a military dominion, which is no government in the, legitimate sense of the term. In the case of California this is now impossible. The Anglo-Saxon foot is already on its borders. Already the advance guard of the irresistible army of Anglo-Saxon emigration has begun to pour down upon it, armed with the plough and the rifle, and marking its trail with schools and colleges, courts and representative halls, mills and meeting-houses (O'Sullivan).

The Congressional Globe of February 11, 1847, reported: Mr. William Fells Giles, representative of Maryland saying, "I take it for granted, that we shall gain territory, and must gain territory, before we shut the gates of the temple of Janus. ... We must march from ocean to ocean. .. . We must march from Texas straight to the Pacific Ocean, and be bounded only by its roaring wave.... It is the destiny of the white race, it is the destiny of the Anglo-Saxon race. ... ." (Zinn 155). U.S. imperial desires to claim Mexican territory moved to action in 1848. The expansion of U.S. territory based on the justified claims of "the white race" proceeded forward. The work of Laura Gómez (2007) uses the territory of what is now the state of New Mexico to trace the origins of Mexican-American as a racial group in the U.S. Her work focused on this process in relation to the codification of race in the law in the $19^{\text {th }}$ century. 


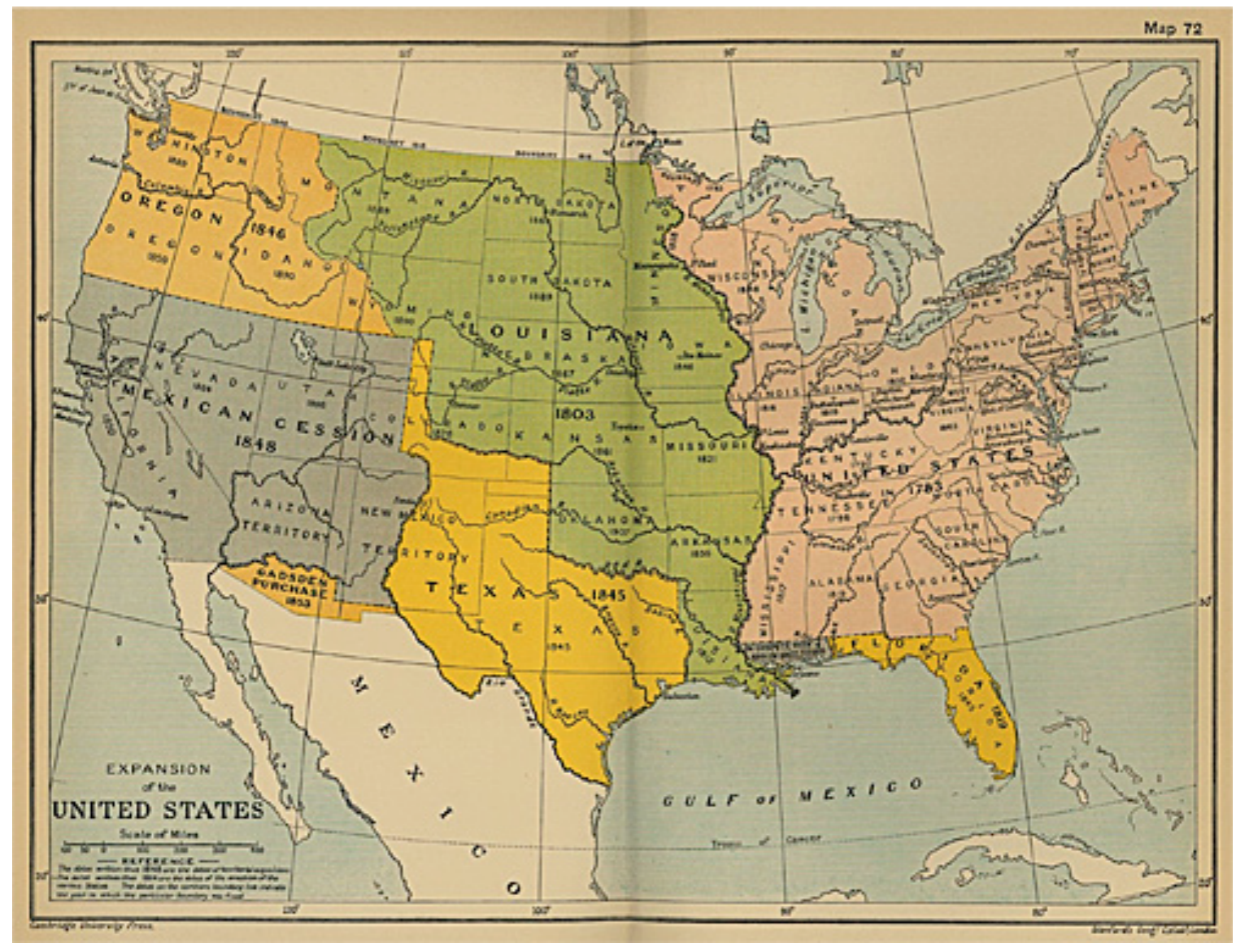

Figure 7. Sir Adolphus Willam Ward, G.W. Prothero, Sir Stanley Mordaunt Leathes, and E.A. Benians, "US Expansion", map, in The Cambridge Modern History Atlas (London, 1912), map 12. Used by Permission of the PerryCastañeda Collection, University of Texas, Austin

An armed clash between Mexican and U.S. troops along the Rio Grande provided the incident for the U.S. to declare war against Mexico. In 1848, at the conclusion of the U.S.- Mexican War, the two countries signed the Treaty of Guadalupe-Hidalgo. The treaty called for Mexico to give up almost half of its territory, which included modern-day California, Arizona, New Mexico, Texas and parts of Colorado, Nevada, and Utah. In return, the U.S. paid \$15 million in compensation for war-related damage to Mexican land.

At the time of the treaty of Guadalupe Hidalgo, approximately 80,000 Mexicans lived in the ceded territory, which comprised only about 4 percent of Mexico's population. Only a few people chose to remain Mexican citizens compared to the many that became United States citizens. Most of the 80,000 
residents continued to live in the Southwest, believing in the guarantee that their property and civil rights would be protected as stated in the treaty of Guadalupe Hidalgo. Sadly, this would not always be the case. By the end of the 19th century, most Mexicans had lost their land, either through force or fraud (see Menchaca, Mexican Outsiders; Menchaca, Recovering History; Pitt).

As the preceding discussion of colonial and national maps makes clear, not only are space and place claimed and codified in shifting frames, these mapping processes also produce racial and ethnic categories as well which are captured in the shifting borders within and between what became the U.S. and Mexico. A long view of more contemporary regional histories of the southwest such as those provided in the recent historical work of Rudy Acuña (Corridors of Migration) and Andrew Truett permit us to understand how legal, cultural, racial, and political borders as well as literal geographical borders were created in the late $19^{\text {th }}$ and $20^{\text {th }}$ century. The parallel and integrated development of the U.S. and Mexican mining and ranching industries in this region along with transportation corridors based on railroad lines also served as corridors of political, cultural, economic, and family transborder relationships that endure to this day and have stretched to include the broader territories of the U.S. and Mexico. Putting the borderlands at the center gives us a crucial optic for understanding the long-term integration and transnational history of the nations now called Mexico and the United States. 




Figure 8. The 1891 Grain Dealers and Shippers Gazeteer, "Atchison, Topeka, and Santa Fe Railroad Route," map, http://www.memoriallibrary.com/Trans/RRGaz/ATSF/map.htm. Used by permission of the MARDOS Memorial On Line Library

Truett's and Acuña's books both focus on the transnational development of the "copper borderlands" in the states of Chihuahua, Sonora, Arizona, and New Mexico in the $19^{\text {th }}$ and early $20^{\text {th }}$ century. These case studies on the links between U.S. entrepreneurial capital, engineers, the U.S. and Mexican governments, local political officials on both sides of the border, displaced native peoples such as the Apache, and Mexican-origin laborers who worked the copper mines provide a map for future trends of capital investment, unofficial border control that has operated outside of "official" policing, heightened nationalism, and debates about the meanings of citizenship.

If anyone ever doubted whether or not the U.S. could be counted as an empire-builder, Truett's account of regional development provides a playbook for how this worked in the building of the transborder copperlands. In a meeting of 
the Democratic Club on New York City's Fifth Avenue in 1891, Walter S. Logan, a Wall Street lawyer who was pushing U.S. investment in Mexico, described his vision for "a landscape of extraction that flowed across national borders" (Truett 2). Logan went on to help entrepreneur William Cornell Greene create the Greene Consolidated Copper Company in conjunction with the Mexican state, and others. Nacozari, Cananea and other northern Mexican mines were connected by railroad to Douglas, Bisbee, Tombstone, Nogales, and beyond. Green's control in the town and mine of Cananea was absolute until the worker's strike of 1906.

Perhaps the most interesting part of Rudy Acuña's study of the same region suggests how opposition politics worked on top of this empire-building economic integration. Acuña documents in great detail how beginning with the creation of beneficence or mutualista organizations for miners that provided death insurance and then through the emergence of labor organizing in Tombstone, Clifton, Morenci, and Metcalf, Arizona, the U.S. side and then the Mexican side of the copper borderlands became centers of labor militancy. By clearly showing the links between leaders of the Clifton-Morenci Strike of 19151916, the presence of sympathizers of the Partido Liberal Mexicano (PLM, founded by Ricardo Flores Magón in 1905), in Arizona, and El Paso Texas, and the mine at Cananea, Acuña documents how labor militancy and then revolutionary Mexican politics were knit together by the economic and transportation system of the copper borderlands region. The regional case studies of Acuña and Truett also provide a historical and conceptual basis for understanding how contemporary drug cartels put their businesses together in the same region, but with expanded operations throughout Mexico and the U.S.

\section{Beyond Mapping: Racialization of Mexicans and U.S. Immigration Policy in the $20^{\text {th }}$ Century}

Until 1924, there was very little control of the U.S.-Mexico border and the mining, railroad, and farming industries were aided by Mexican workers. Earlier exclusion laws such as the Chinese Exclusion Act of 1892, the Gentleman's Agreement of 
1907 between Japan and the U.S., and the 1917 immigration act which created the Asiatic-barred zone excluding most Asians from the U.S. except Japanese who were needed to harvest sugar beets-all these prior policies foreshadowed the contradictory nature of U.S. immigration and border policy towards Mexico in ways that continue today. By 1917, people excluded from entering the United States included "all Asians, illiterates, prostitutes, criminals, contract laborers, unaccompanied children, idiots, epileptics, the insane, paupers, the diseased, and defective, alcoholics, beggars polygamists, anarchists, and more" (LytleHérnandez 27). When foreign laborers are needed, the real and metaphoric border is more open, but when national politics and economics require a scapegoat, "foreign workers" and immigrants get the blame for many of the country's problems. As we can see, the national and ethnic target of who the "problem immigrant population" is can change through time, but the moral assertion of who has the right to be here and who does not remains. Because of the historically subordinate status of Mexico as a nation to the U.S. since 1848 and the ongoing racialization since that time of people of Mexican descent as "foreign," the metaphoric U.S.-Mexico border and who belongs on which side of it has been an ongoing source of contention and public debate.

Beginning with the establishment of the U.S. border patrol in 1924 and the he Immigration Act of 1924, or Johnson-Reed Act, people of Mexican descent have increasingly been constructed in popular and political discourse as "illegal aliens," a racialized category which is often generalized to all brown, Latino "looking" persons-whatever their citizenship, national original, legal status, education, class, or gender. As argued by Mai Ngai in an insightful article on "The Strange Career of the Illegal Alien," the advent of mass illegal immigration and deportation policy under the Immigration Act of 1924 altered meanings of inclusion in and exclusion from the nation:

The process of territorial redefinition and administrative enforcement informed divergent paths of immigrant racialization. Europeans and Canadians tended to be disassociated from the real and imagined category of illegal alien, which facilitated their national and racial 
assimilation as white American citizens...Mexicans emerged as iconic illegal aliens. Illegal status became constitutive of a racialized Mexican identity and of Mexicans' exclusion from the national community and polity.

After passing the National Origins Act of 1924, a few days later Congress set aside one million dollars to "establish a 'land-border patrol' of the Immigration Bureau of the U.S. Department of Labor" (Lytle-Hérnandez 32). Historian Kelly Lytle-Hérnandez argues that the establishment of the U.S. border patrol in the Texas-Mexico borderlands enabled working class laborers (mostly white, but some Mexican-American) to move into stable law enforcement positions with authority and that they also "found a unique way to participate in the agricultural economy: they policed the region's workforce" (45). Because border patrol officers had a great deal of control over not only enforcement activity on a daily basis but also over the direction that future immigration law enforcement took, Lytle-Hernandez suggests that local officers "also created a new axis of racial division in borderlands communities by linking Mexican immigrants to the crime, conditions, and consequences of being illegal in the United States" (45). The U.S. racial narrative linking Mexican nationality with illegality and perceived "Mexican" physical appearance as "brown" began on the southern borderlands in the 1920s through law enforcement practices and linguistic categories. The hardening of the U.S.-Mexico border after 1924 and the creation of "legal" and "illegal" forms of migration and migrant status created two streams of Mexican migration to the U.S. While Mexican officials and researchers such as anthropologist Manuel Gamio had previously extolled the virtues of mass emigration to the U.S. because it raised household income through remittances (Mexican Migration 30), "the transformation of mass labor migration to mass illegal immigration converted the profits of labor emigration into the problems of illegal immigration" for the Mexican government (Lytle-Hérnandez 89-90). The narrative of illegality thus has an impact on Mexican policy as well, resulting in efforts to prevent smuggling of undocumented workers over the border that began in the 1920s and continued with the Bracero program. The racial narrative 
of the "Mexican illegal" was scripted on both sides of the southern border and spread from there to the rest of the country.

Mexican labor was viewed as a desirable alternative to other immigrant labor because, in the words of lobbyist S. Park Frisselle (who reported to the Fruit Growers Convention in 1927), "As you know, the Mexican likes the sunshine against an adobe wall with a few tortillas and in the off time he drifts across the border where he may have these things... If charity spends one dollar on the Mexican in California, the State profits two dollars by having him here. The Mexican can be deported if he becomes a country charge, but the others are here to stay" (McWilliams 127). While large farms used Mexican labor during the growing season until the early 1930s, during the winter months workers went to nearby cities where some became a part of relief programs aimed at the poor.

Historically, it was not only the border patrol that acted to restrict the movement of Mexicans in the U.S. and to deport them. After the depression became entrenched in the early 1930s, William N. Doak, Herbert Hoover's newly appointed secretary of labor sent immigration officers throughout the country searching for "illegal aliens." Although Mexicans were not supposed to be the only targets, they appear to have been the majority of people either deported or intimidated into departing voluntarily. During the Great Depression, local authorities throughout the Southwest and Midwest repatriated up to one million Mexicans during the early 1930s (Balderrama and Rodríguez; Valenciana). Approximately 60 percent were children of American citizens by native birth (Ngai, Impossible Subjects 72). By the Great Depression, the population of Mexicans in the U.S. was over 1.4 million. Once the U.S. entered World War II after the Japanese attack on Pearl Harbor on December 7, 1941, the position of Mexican laborers was once again reassessed in relation to U.S. interests.

In order to bridge the gap between the increasing demand for agricultural workers and their decreasing numbers among the U.S. population, in 1942, Public Law 45 was created to appropriate the necessary funds to implement an executive agreement with Mexico to import thousands--and eventually millions-of guest workers or braceros. Although the Bracero Program was created to 
alleviate wartime labor shortages, it lasted until 1965. Millions more workers were contracted in the period after the end of World War II $(4,746,231)$ than during the war itself $(167,925)$ (Carrasco 203, n. 50). The Bracero Program allowed the importation of Mexican workers for annual harvests with the stipulation that they were to return to Mexico after their work was finished. Braceros were contract workers who were supposed to have certain guarantees met in terms of housing, transportation, wages, recruitment, health care, food, and the number of hours they worked. The contracts-initially negotiated directly between the U.S. and Mexican governments-even stipulated that there should be no discrimination against the braceros. However, compliance officers, including Mexican consular officials, were few and far between. Later contracts were switched to private contractors in the U.S. Most growers and the U.S. government ignored the terms of the contracts but the braceros had no recourse. After the initial agreement with Mexico for the Bracero Program expired in 1947, the program continued for agricultural workers under a variety of laws and administrative agreements. It was terminated in 1964.

Along with the legally contracted male, temporary agricultural and railroad workers of the Bracero Program came many other Mexican nationals who crossed illegally into the United States. These might have included those who could not get a contract, who didn't want to be limited by the temporary natures and time constraints in the Bracero Program or who for other reasons were not bound by the legal process. Rapid industrialization of Mexican agriculture in the 1940s, an increase in population, and food shortages pushed people to the North (Lytle-Hernandez 113). Unsanctioned border crossings in the 1940s were of concern to the Mexican government as well as to the U.S. government.

The Mexican government became increasingly concerned with the greater flow of Mexican workers north, both as braceros and undocumented workers. Mexican agribusinessmen, particularly from the cotton industry, pressured the Mexican government to end unsanctioned migration to the U.S. (Lytle-Hérnandez 114-117). In 1943, the Mexican Embassy in Washington D.C. "warned the U.S. Department of State that if control was not established over the flow of illegal 
immigration into the U.S., Mexico would 'effect a complete revision of the [Bracero] program agreements"' (Lytle-Hernández 117). The result was that by 1944, the chief supervisor of the Border Patrol, W. Kelly began an "intensive drive on Mexican aliens" by deploying what were called "Special Mexican Deportation Parties" (Lytle-Hérnandez 117). Kelley increased border patrol personnel and by November of 1944, 42, 928 Mexican nationals had been deported out of California (Lytle-Hérnandez 117). The numbers continued to increase and were formalized in the 1950s as "Operation Wetback." Importantly, the contradictory policy of both inviting Mexicans in as legally contracted workers under the Bracero program and deporting those who came to work without documentation as "illegals" involved Mexican policy makers as well as those in the U.S.

On the U.S. side, bracero workers were welcome as long as they were obedient and did not question the terms of their labor contracts. At the end of the bracero program in Oregon in 1947, for example, the labor camps were closed, and all contracted laborers were supposed to return to Mexico. Not all of them did and there were other workers already in the state who were undocumented as well. In Oregon, use of the label "illegal" for Mexican workers can be traced most recently to changes in the ways that contracted workers were categorized while working under the Bracero Program from 1943-1947 and then afterwards. There, bracero workers went from being written about as heroes when they arrived in the state in 1943 and 1944 in headlines such as "Wheat Saved by Mexicans," "Mexican Harvesters Doing a Great Job in Fields and Orchards..." to being called "wetbacks" and "illegals" by the late 1940s and early 1950s in the same newspapers. The racialized discourse of illegality, criminality, and Mexicanness that solidified on the southern border in 1924, became generalized throughout the U.S. in the 1940s and 1950s. The Border Patrol's project of policing unsanctioned Mexican immigration clearly intensified, "resulting in 474,720 interrogations reported by the U.S. Border Patrol in 1940 to 9, 389,551 in 1944" (Lytle-Hérnandez 120). The total number of Mexicans deported and 
departing voluntarily to Mexico was 16,154 in 1943. By 1953 , that number was 905, 236 (Lytle-Hérnandez 122).

The 1950s were also marked by "Operation Wetback," a program focused on preventing undocumented people from entering the U.S. and on rounding up and deporting undocumented people already here. While this was its tactical packaging, according to historian Lytle-Hérnandez, "mass deportation, or at least the threat of mass deportation" was seen by Border Patrol Commissioner Swing and others as a means for confronting the interrelated crises of control along the U.S. border and consent among influential growers who "refused to concede to a new era of migration control" (169).

In Oregon and other states, the newspaper headlines from Operation Wetback helped to cement the racialization of people of Mexican origin as "illegals" in regional political narratives. A newspaper article in the Oregonian on May 15, 1953, ran with the headline, "Agents Sweep Rising Tide of Mexican Illegals South to Border." The paper reported, "Most of Portland's deportees are flown to Los Angeles. The immigration service flies them from there to Guadalajara, about 1500 miles south of this border, just to discourage them from returning so quickly. Now the flood of wetbacks is so great they are being swept back just to the border" (Richards 4). The culture of immigration raids and the right of INS agents to detain "foreign-looking" workers in any location became entrenched and continues to this day.

It is widely agreed by scholars of immigration that past U.S. immigration policies-particularly the U.S. Bracero program of 1942-1964 which resulted in 4.5 million Mexican nationals being legally contracted for work in the United States (some on multiple contracts) and the 1986 Immigration Reform and Control Act (IRCA) and the Special Agricultural Worker's Program (SAW) which resulted in the legalization of nearly 3 million people-have had a large hand in setting up current patterns of immigration. In November of 1986, President Reagan signed the Immigration Reform and Control Act (IRCA), which allowed those who had been living undocumented in the US since January 1, 1982, to apply for amnesty and legal temporary residency, and then permanent 
residency. In addition, any person who worked in agriculture for ninety days between the period of May 1, 1985, through May 1, 1986, could receive temporary residence and later permanent resident status through the Special Agricultural Workers program (SAW). On this basis, farmworkers also received temporary residency. IRCA conferred legal status on nearly 3 million undocumented immigrants whose family members then became eligible for permanent residency in the U.S. As discussed by Phil Martin, while policy makers had hoped that IRCA would decrease unauthorized immigration and increase real farm wages, instead it accelerated the spread of unauthorized Mexican workers throughout U.S. agriculture and reduced wages (183). Once they were legalized, SAW workers could live and work anywhere in the U.S. While most legal and undocumented farmworkers were found in western states, Texas, and Florida before 1986, after 1986 legalized SAW workers spread throughout the U.S. As Martin documents, "Pioneer SAWs served as anchors for the unauthorized workers who continued to arrive in the United States from their hometowns, giving rise to phrases that described Mexican immigration as the "changing face of' or 'Latinizing" of rural America" (187). In addition, employers began hiring unauthorized workers through labor contractors all over the U.S. This left many workers worse off, reducing earnings by 30 to 40 percent according to Martin (187). Additional immigration legislation by the Bill Clinton administration further undermined the ability of relatives of those who had received amnesty in 1986 to become legal residents due to increased income requirements.

The 1996 Illegal Immigration Reform and Immigration Responsibility Act (IIRIRA) expanded the definition of deportation removals to include people who used to be excluded at the border as well as people deported from the interior of the United States. IIRIRA also made it more difficult for people to sponsor relatives to come to the United States by increasing income requirements from at or above 100 percent of the U.S. poverty level to at or above 125 percent of the U.S. poverty level. In 1998, this was close to $\$ 20,000$ for a family of four. In 1999 this is about $\$ 24,000$. It also set deadlines for when people already in the U.S. 
could apply through their families for residency. If you missed a 1998 deadline you had to leave the country and apply from your home country. This law was revised with a "sunset" clause under Clinton and this was extended by Bush, giving divided families a new chance within new deadlines to apply for residency without undocumented members having to leave the U.S. and apply from their home countries. The application cost ( $\$ 1000$ plus lawyer fees) plus minimum income levels still make this difficult for those such as farmworker families who average about $\$ 8,000 / y$ r. Clinton's other branch of immigration policy-border security—also had a major impact on immigrant communities.

Beginning in 1994, U.S. border defense policy moved away from internal detentions to fortifying the border in highly trafficked crossing points through the construction of large walls and other barriers, use of high-tech equipment to track migrants, increased numbers of border patrol agents, and a new system of identification linked to fingerprinting all who are detained. Operation Gatekeeper was launched in the San Diego/Tijuana area. By early 1998, Operation Gatekeeper had been in place for more than three years and arrest rates fell significantly. The second phase of the border "defense plan" focused on classic crossing routes in central Arizona and south Texas. The enforcement offensive south of Tucson, dubbed "Operation Safeguard" was launched just a few weeks after Gatekeeper in San Diego. By 1999 defense walls and agents were being planted along the full length of the border. Operation Rio Grande targeted the zone of South Texas focused on McAllen, Brownville, and Laredo. Arrests were dropping in these sectors. The outcomes of these efforts were that greater numbers of migrants attempted to cross in the rugged mountains to the west of San Diego in Imperial County. Here people began dying in the cold of winter. Others were pushed into the desert in western Arizona. Significantly increased migration during the 1990s coupled with a border defense policy that squeezed people into extremely rugged terrain in California and increasingly in Arizona produced hundreds of migrant deaths every year. In 2009, there were 221 Arizona border deaths recorded by the Border Deaths Data Base of the Arizona Star. 
In April of 2010, Arizona governor Jan Brewer signed into law SB1070 aimed at identifying, prosecuting, and deporting undocumented immigrants. The law gave police broad power to detain anyone suspected of being in the country illegally. While U.S. District Judge Susan Bolton issued a preliminary injunction suspending several key provisions of the law, which were to come into force on July 29, 2010, this didn't stop the political and cultural force of the Arizona law in the U.S. In 2010, lawmakers in other states introduced or planned to introduce similar legislation. In many ways, SB1070 codifies the long process of the racialization of Mexicans in the U.S. as "illegal" that began in the $18^{\text {th }}$ century and welds it to the militarization of the U.S.-Mexican border by official and unofficial forces (see Chavez; Doty). While such a conclusion is sobering from a structural perspective, we also need to remember Mexican immigrants and migrants as active subjects who have agency in producing significant ideas and discourses themselves. A transborder perspective allows us to bring these subjects and their agency into focus.

\section{A Transborder Perspective: Communities}

Because of a long history of political, economic, and social integration with Mexico as well as a result of U.S. and Mexican labor and immigration policies, today a majority of communities in Mexico are transborder communities. Such communities are full of people accustomed to living in multiple localities and discontinuous social, economic, and cultural spaces. People here have worked out a social world that exists within a multi-sited existence. One Mixtec community I have carried out fieldwork in since 2004, San Agustín Atenango in Oaxaca, does not exist in one geographic place, but is now present throughout multiple sites in the U.S. and Mexico. Spread out in at least thirteen different locations in the U.S. as well as others in Mexico, the home community of Atenango sports many empty houses, signaling both the presence of remittances to those who remain and coordinate family building projects and the strong presence of the people of Atenango in other locations. A review of different 
generations of migrants and immigrants from Atenango can be connected to the different sites.

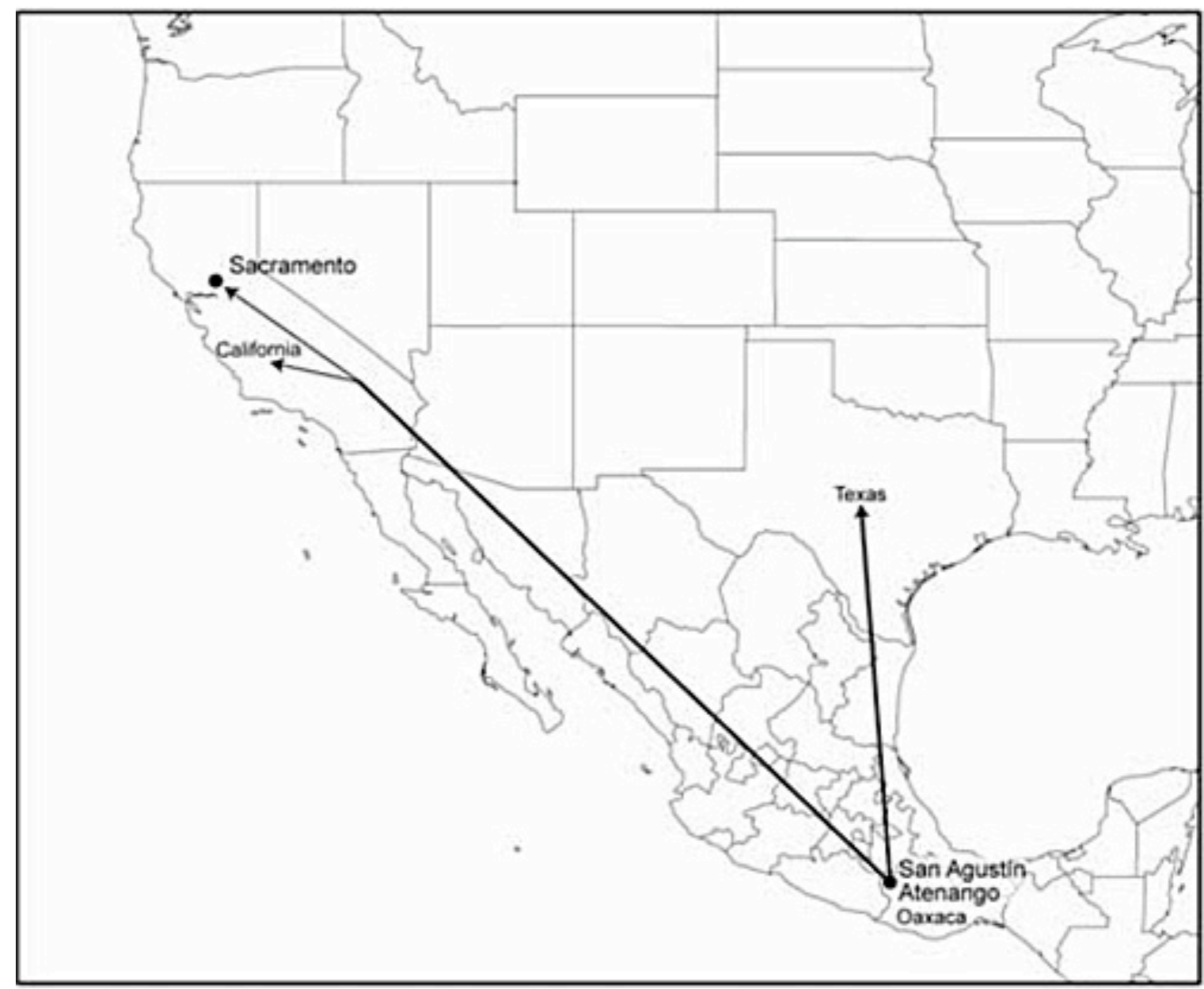

Map X. San Agustin Atenango Bracero Program Migration, 1942 - 1964.

Figure 9. Lynn Stephen, Transborder Lives: Indigenous Oaxacans in Mexico, California, and Oregon (Durham, 2007), 112.

José Luis García López was born in 1936. He worked as a bracero worker in California and Texas from 1953 until 1964. Prior to that, he went to work in Veracruz harvesting coffee and sugar cane. After being a Bracero, he worked as a farm laborer in Sinaloa and Baja California with his wife and children. He has not returned to the U.S., but his son is living and working in Santa Maria California while his wife and two children remain in San Agustin. Many other men from his community were braceros as well from the 1940s to the 1960s. The map above shows his paths of migration to the U.S. as a bracero. 


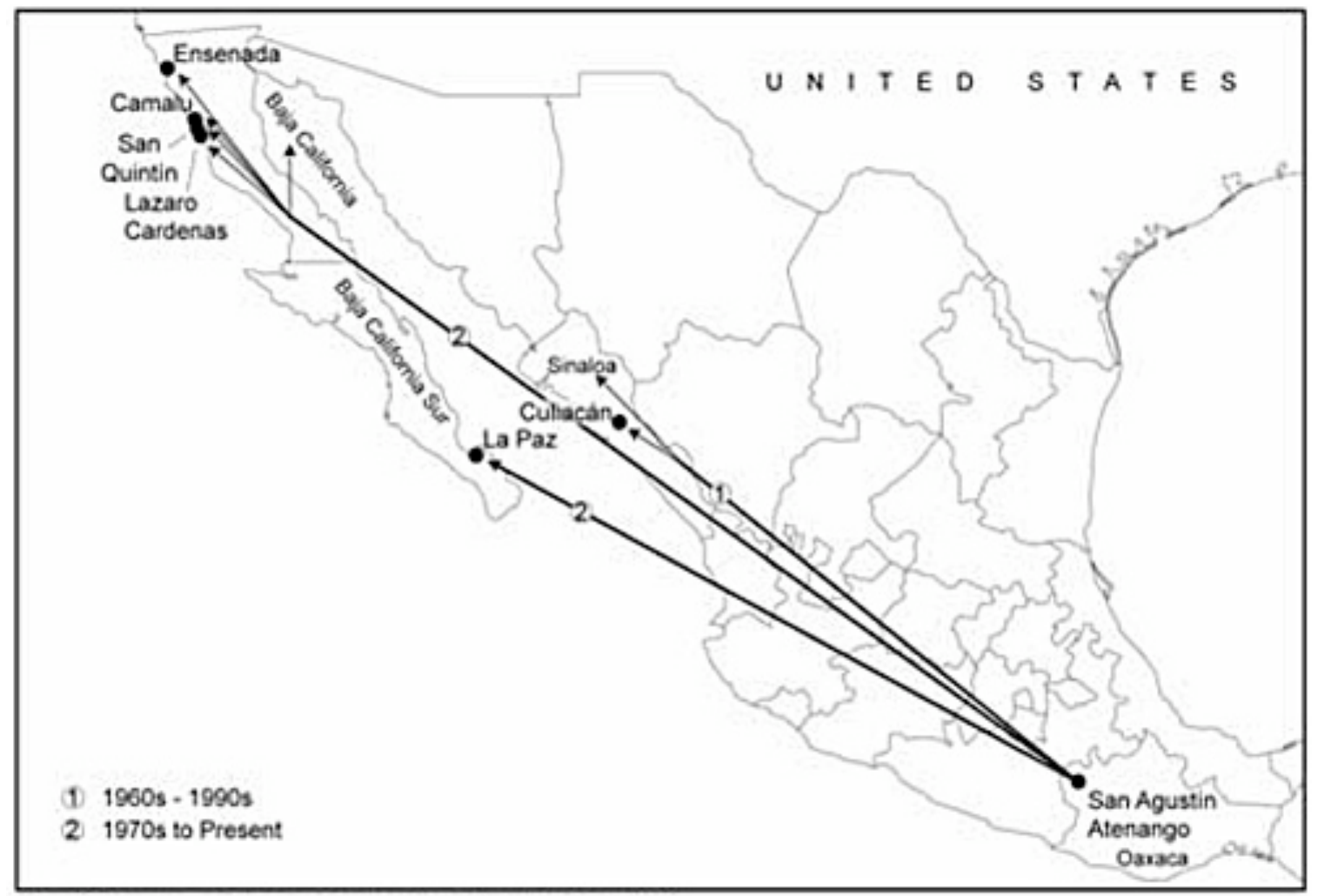

Map X. San Agustin Atenango migration paths, $1960 \mathrm{~s}-1990 \mathrm{~s}$

Figure 10. Lynn Stephen, Transborder Lives: Indigenous Oaxacans in Mexico, California, and Oregon (Durham, 2007), 115.

Many families in San Agustín also have one or more people who were regularized as a part of the 1986 IRCA or SAW program. They were present in California or other places in the 1980 s and were able to legalize. Other family members who worked in the 1980s in the U.S. may not have qualified for legal residency, but came anyway because they had a legalized relative. From 1995 to 2005, migration from San Agustín and many other communities greatly increased to the U.S. and spread to many different places. Petrona Martínez Reyes, Luis Reyes Guzman, Laura Martínez Reyes, and Esmerada Martínez Reyes are representative of such families. In addition to the four of them currently living in San Agustín Atenango, this family includes two other people, Luis Junior living in Santa María, California, and another sister Aurora, living in Oxnard, California.

Petrona was born in 1943. Her husband Luis was born in 1942. Both of them went to the state of Veracruz as children to harvest sugar cane. Luis never went to the U.S. as a bracero, but when he and Petrona were married in the 
1960s, they began to migrate north to Culiacan, Sinaloa where they both worked harvesting tomatoes. They would periodically come home to build parts of their house, going back and forth every year with their young children. In the 1980s they went to work in Baja California and took their children with them. Laura (born in 1976), Esmeralda (born in 1978), Aurora (born in 1968), and Luis Junior (born in 1970) went with them to La Paz where they picked cotton.

While Luis, Laura, and Esmeralda stayed in San Agustin Atenango, Petrona, Aurora, and Luis Junior worked for ten years in Oxnard, Watsonville, and in San Diego. Luis Junior and Aurora became legal permanent residents in 1986 through the Special Agricultural Worker's Program related to IRCA. Petrona returned to Mexico during 1986 and lost the opportunity to become legalized. Laura went to San Diego in 1995 and through a contact of her older sister, Aurora, found work taking care of children for three years. She returned to San Agustín Atenango in 1998 to take care of her father Luis when he became very ill. She has not returned to the U.S since that time. 


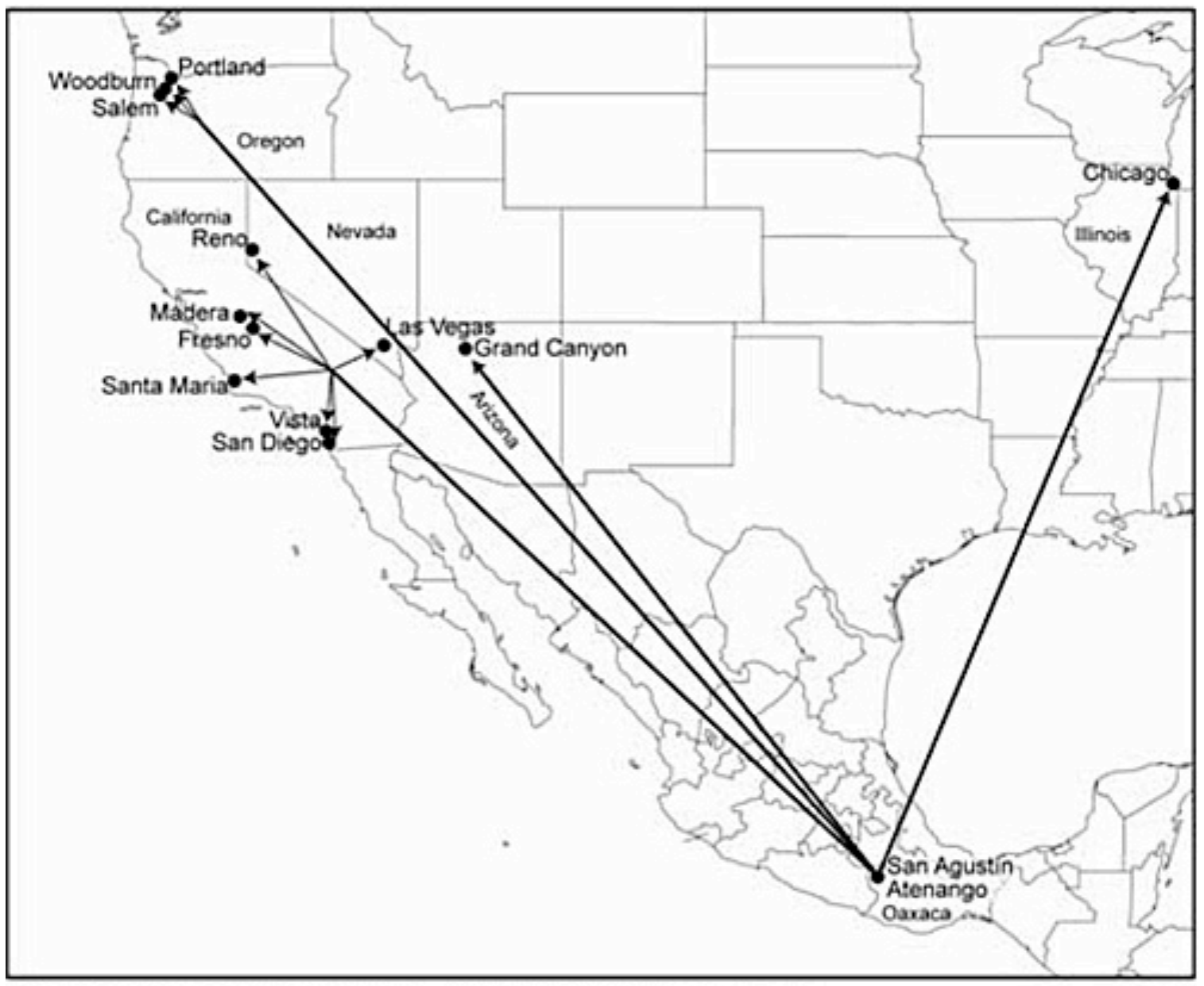

Map X. San Agustin Atenango migration to the U.S. - late 1970 s to present.

Figure 11. Lynn Stephen, Transborder Lives: Indigenous Oaxacans in Mexico, California, and Oregon (Durham, 2007), 115.

As a "hometown," thus San Agustín Atenango is both a real and symbolic site that draws people back repeatedly in many senses, but which is also represented by multi-layered forms of social and political organization that include a federated transborder public works committee in 13 U.S. cites as well as in several locations in Mexico, all linked to San Agustín in Oaxaca. We can think of each location of San Agustín as a "home" and as a locality in its own right with real senses of the "local." But these multiple homes of San Agustín are also discontinuous spaces linked through kinship, ritual, cycles of labor, and individual and collective resources of material and symbolic means (see Besserer). 


\section{Borders, Border Crossing, and Borderlands}

With this historical policy and ethnographic discussion in place, let's explore the reasons why an analysis based on multiple and shifting borders can be helpful in understanding U.S.-Mexican relations and how people experience migration and immigration. People who migrate and immigrate have multiple dimensions to their identity including region, ethnicity, class, and race. Age, gender, and sexuality are also important dimensions of the identities of migrants and immigrants but are not discussed here (see Cantú; Dreby; González-López; Wilson; Zavella). If we only refer to their nation of origin or "nationality" and/ or to the specific nation(s) they come to reside in as a result of migration or immigration then we miss understanding how people experience immigration on different levels and also how the identities of migrants and immigrants are reconstituted along multiple dimensions. The concepts of borders, border crossing, and borderlands may be more fruitful analytical terrain for understanding migrant and immigrant communities than a focus that centers only on the national and transnational. The crossing of many borders and the carrying of these borders within one's experience allows us to see migration and immigration in terms of family relationships, social, economic, and cultural relationships, communities, and networks beyond the legal relations that individuals have with nation states and the physical border between the U.S. and Mexico.

While one may be moving across borders, another way to conceptualize borders is in terms of the geographic and metaphorical spaces that they represent. Such spaces are often known as borderlands. Borderland scholarship_particularly of the U.S.-Mexico borderlands-has produced some of the most insightful cultural, political, and economic analyses of this integrated region of the U.S. and Mexico. Chicana lesbian feminist poet and intellectual Gloria Anzaldua had widespread influence on the way that the concept of borderlands is understood that is useful here. Her concept of borderlands includes the geographical space around the U.S.-Mexico border, but she also 
conceptualizes Borderlands as a metaphorical space that accompanies subjects to any location.

While earlier borderlands scholarship often focused on the geographically circumscribed border region of the U.S.-Mexico border, more recent scholarship has merged with many of the concerns of scholars of transnationalism. For example, a volume edited by Denise Segura and Pat Zavella, Women and Migration in the U.S.-Mexico Borderlands, uses an expanded concept of borderlands to consider all of the U.S. and Mexico as potential parts of the borderlands. This is not unlike Nicolas De Genova's suggestion that cities with significant populations of immigrants from Latin America be considered as a part of Latin America. He suggests the specific concept of "Mexican Chicago" in relation to the large number of Mexican immigrants there (De Genova, "Race, Space" 89-90; Working the Boundaries). Offered as a corrective to perspectives that see Latin America as "outside the United States," and assimilation as the logical and desirable outcome of migration, De Genova suggests that "rather than an outpost or extension of Mexico, therefore, the 'Mexican'-ness of Mexican Chicago signifies a permanent disruption of the space of the U.S. nation-state and embodies the possibility of something truly new, a radically different social formation" (Working the Boundaries 190).

Conceptualizing the idea of borderlands to represent connected spaces (geographic, political, social, cultural, and economic) that encompass multiple locations both on the literal border and in particular nation-states does not eliminate, but decenters the nation-state as the primary actor in immigration along with the individual.

\section{Colonial Borders: Racial and Ethnic Hierarchies Written into Nationalism}

A border optic on migration and immigration which is multidimensional also permits us to deal with the issue of time compression in the ongoing construction, crossing, and codification of borders. An ongoing challenge for migration frameworks that focus primarily on movement between contemporary nationstates is in dealing with borders that have both current and historical dimensions 
to them. Specifically I want to raise the issue of the ways in which past colonial borders and categories linked to colonial states permeate the experiences of migrants today. Coloniality is understood as the ongoing vestiges of colonial processes of subjectification and identification that are the underside of modern states.

Coloniality persists after the formal end of colonial political regimes through the ongoing presence of colonial racial, ethnic, gender, and class hierarchies (see Quijano; Mignolo). Such hierarchies are often submerged in the political culture of nation-states and are ever-present as a part of nationalism. For example, after the Mexican Revolution (1910-1920), the promotion of mestizaje (supposed mixing of "Spanish and Indian") as a nationalist ideology was pushed in tandem with policies focused on incorporating the indigenous population. Writers such as Manuel Gamio who called for the fusion of the races (Forjando Patria), and José Vasconcelos' writings about "the cosmic race" reinforced the nationalist idea of Mexico as a one-race nation. This one race, the mestizo, required the erasure of "the Indian" and "Afro-descendents".

Why do borders of coloniality matter in a discussion of contemporary migration?

Afro-descendent and indigenous peoples are often glorified in histories of nationalism, but continue to struggle to obtain equal rights and recognition within the framework of many nation-states, even after they have won legal recognition in state constitutions. The fact that indigenous, Afro-descendent, and often women have to continue to demand "equal" rights is a manifestation of coloniality in many contexts. When Afro-descendent and indigenous peoples immigrate as part of a "national" group, they often face multiple forms of discrimination in the host context. They are discriminated against because of their national identity, but may also be further discriminated against by their fellow national immigrants for their racial and/or ethnic identity.

Within Mexico, indigenous peoples are incorporated into a coloniallyinherited system of merged racial/ethnic classification where they are ranked below "Mestizos" (a constructed category of "mixed race") and "White Spaniards" 
who supposedly have preserved their Spanish heritage over 500 years (See Stephen, Zapata Lives 85-91). While such categories are certainly historically and culturally constructed and not biological, they continue to operate with political and social force in many parts of Mexico as well as among Mexicanorigin populations in the U.S. For indigenous migrants who have come to the U.S., the racial/ethnic hierarchy of Mexico continues, but is also overlaid with U.S.-based racial categories.

Contemporary racial hierarchies in the United States are products of the process of U.S.-empire-building linked to ideologies of Anglo superiority such as Manifest Destiny. The saying has consistently been used to justify U.S. expansion as "Anglo Saxons" bring democracy, progress, and enlightenment to "lesser" peoples, including American Indians, Mexicans, the Philipinos, Puerto Ricans, and others (see Acuña, Occupied America). As Ana Alonso points out, the discourse of Manifest Destiny conflated national origin and race (232). If Anglo-Americans were at the top of a racial/ethnic hierarchy, then Mexicans, American Indians, and Africans were at the bottom. The ethnic/racial formations linked to U.S. nationalism have a strong impact on Mexican immigrants as do the ethnic/racial hierarchies produced by Mexican nationalism. And in both countries there are specific regional variations and histories of these larger ethnic/racial hierarchies.

Whereas "ethnic" distinctions are the primary markers of difference in Mexico, particularly in terms of how much people embrace an indigenous identity built on place, language, and ethnic autonomy, once Mexican migrants cross into the U.S., what was their national identity, i.e. "Mexicanness," becomes treated as a racial identity. Scholars of Latino Studies are increasingly taking on the racialization of cultural and ethnic categories in analyzing the varied experiences of Latinos in the U.S. (Fox). The construction of all Mexicans historically as "illegal" or "potential illegals" also involves a process of racialization in the $19^{\text {th }}$ and $20^{\text {th }}$ centuries-with regional specificities.

We can use the borders of coloniality in both Mexico and the U.S. to understand the ways in which indigenous Mexican migrants become and 
continue to be a racialized category in the U.S. within the Mexican immigrant community and how Mexican systems of ethnic and racial classification are influenced by and overlap with the historically and regionally-situated racial hierarchies in the U.S.

\section{The Role of States}

While I have consistently made an argument here for using the term "transborder" community over "transnational" in order to partially decenter the position of the nation-state and national identity in how we conceptualize multisited migrant communities and the experiences of their members, it would be foolish to argue that we can write the state out of this discussion. Economic policy, trade policy, immigration policy, anti-drug policy, and national security policy are all arenas in which the nation-state is central and can profoundly affect transborder communities. In the U.S. the convergence of several different "wars" on the U.S.-Mexico border, the construction of additional border walls, and the Bush and Obama administrations' policy of raids on worksites and in residential areas with undocumented employees has made the state a common presence in transborder communities and families through their encounters with U.S. Immigration and Custom Enforcement (I.C.E.) officials.

Tony Payan makes a compelling case for how the 2002 reorganization of the Homeland Security Department conflated three different "wars"- the war on drugs, the war over the enforcement of immigration laws, and the war on terrorinto one and has placed them all on the U.S.-Mexico border. The "wall" is supposed to hold "illegal aliens," "drugs and those who distribute them," and terrorists at bay. The unified "war," Payan demonstrates, has incorporated the strategy, tactics, personnel, resources, rhetoric, and hardware of militarization. The effects for those who live in the borderlands in places such as the forty three border counties of Texas that are among the poorest in the U.S. are infrastructure and socio-economic deficiencies, enormous income inequality, and daily danger (138). 
The politics and strategies of "homeland security," policing, and deportation as part of anti-gang, anti-terror, and anti-drug policy have become integrated with larger U.S. immigration policy to build a wall of exclusion and create blurred borderlands such as the ones found in U.S. and Salvadoran prisons for gang members and particular neighborhoods of the cities of Los Angeles and El Salvador. Increased use of raids in places of employment in the U.S. has brought the policing of the U.S.-Mexico border into all Latino immigrant communities in the U.S., including those far from the border in locations such as Postville, lowa where in May of 2008, I.C.E. authorities arrested nearly 400 people and tore families apart (Hsu, "Immigration Raid" 1A). The day following the raid, 90 percent of Hispanic children were not present in school as their parents had been arrested. According to the U.S. attorney's office for the Northern District of lowa, those detained included 290 Guatemalans, 93 Mexicans, 2 Israelis and 4 Ukrainians (Hsu, "Immigration Raid" 1A). The deported workers were replaced with Somali immigrants just two months after the raid. This is certainly a powerful demonstration of the capacity of the state to reconfigure transborder communities.

\section{Conclusions}

Transborder communities have complex current and historical trajectories that require a sophisticated array of analytical tools. Here I have emphasized the concepts of borders, border crossing and borderlands as a different optic for understanding how individuals and communities living in time and space compressions are able to build connections in multiple spaces at once and can construct, maintain and rework identities which incorporate disparate forms of racial, ethnic, regional, national, gendered, and kin relations. In this discussion, I have specifically sought to take apart the homogeneity of nationalism as projected across borders and to emphasize the importance of regional histories of colonialism and the racial and ethnic hierarchies attached to this history. I have emphasized a disarticulated sense of border crossing, examining the multiple borders that migrants and immigrants cross, maintain, and re-articulate through 
their daily lives. I used the strategy of examining first the colonial mapping of place, space, people, race, and ethnicity in the American hemisphere and then argued that this colonial mapping is reworked and solidified in the racialization of Mexicans in the U.S. as "illegal" through U.S. immigration policy towards Mexico in the $19^{\text {th }}$ and $20^{\text {th }}$ centuries. I have suggested that we conceptualize transborder communities as linked together through networks that connect them not only to their home communities, but also to a wide range of other social actors, institutions, and communities in their host environment. If we have a multilayered, historically complex, and contemporarily rich picture of all of the borders that migrants cross and carry with them into multiple situations and places then we get a sense of the counterweights that exist to the power of nation-states to impose legal and physical borders in peoples' lives, to police their own boundaries at any time or place, and to forcibly move and remove those who are excluded.

While it is clear that the construction of walls does not stop people from coming, analytically and historically deconstructing the notion of a fixed border/wall between the U.S. and Mexican nations also helps us to see how contemporary borders shift as well. Such an approach can help us to revamp formal immigration policy to match the reality of U.S.-Mexican life. We need a realistic and comprehensive approach which should minimally include: a path to earned citizenship, family unification, a safe, legal, and orderly avenue for migrant workers to enter and leave the U.S., labor protections for all workers, and border enforcement policies that protect the nation's security from those who truly endanger it while protecting the human rights of all individuals. Such a policy would suggest that we can move beyond the border and a border wall as ideological weapons. Instead, we can embrace the reality of extended borderlands and ensure that all the people within them are respected and included. 
${ }^{1}$ This article draws on some ideas and arguments published in a shorter version of this article as Lynn Stephen. 2012. "Towards a Transborder Perspective: Place, Space, People, and Race in U.S.-Mexico Relations" published in Iberoamericana, No. 48, a special issue titled, "Entre espacios:

Entrelazamientos y movimientos en América Latina en la globalización histórica y actual." Berlin.

${ }^{2}$ The U.S. Customs and Border Protection (CBP) had awarded 13 task orders to Boeing for a total amount of approximately $\$ 1.1$ billion. The orders are for Secure Border Information network technology. "SBInet surveillance technologies are to include sensors, cameras, and radars. The command, control, communications, and intelligence (C3I) technologies are to include software and hardware to produce a Common Operating Picture (COP) - a uniform presentation of activities within specific areas along the border" (Government Accounting Office 1). In March of 2010, however, the Obama administration halted worked on the high tech virtual part of the fence to divert some $\$ 50$ million dollars to other border security projects.

${ }^{3}$ Recent research of Wayne Cornelius and others among Oaxacan migrants found that the probability of returning from the U.S. to Mexico among undocumented Oaxacan migrants went from a high of 20 percent in 1982 to a low of 5 percent in 2004 (Cornelius et. al).

${ }^{4}$ These headlines are from (in order), "Wheat Saved by Mexicans," The Oregonian, October 11, 1944; "Mexicans Aid Flax Industry," The Oregonian, October 14, 1944; "Mexican Harvesters Doing a Great Job in Fields and Orchards, Say Growers and Farmers Who Have Seen Them Work," The Oregonian, October 3, 1943.

\section{Works Cited}

Arbingast, Stanley A., et al. "Mexico at the time of Conquest, 1519." Map. Atlas of Mexico. Austin: Bureau of Business Research, U of Texas, Austin, 1975. Web. 16 June 2010.

---. "The Viceroyalty of New Spain, 1786-1821." Map. Atlas of Mexico. Austin:

Bureau of Business Research, U of Texas, Austin, 1975. Web. 16 June 2010.

Acuña, Rudy. Corridors of Migration: The Odyssey of Mexican Laborers, 16001933. Tucson: U of Arizona P, 2007. Print. 
---. Occupied America. New York: Longman, 2000. Print.

Alonso, Anna. "Borders, Sovereignty, and Racialization." A Companion to Latin American Anthropology. Ed. Deborah Poole. Malden: Blackwell, 2008. 230-254. Print.

Anzaldua, Gloria. Borderlands/La Frontera. San Francisco: Aunt Lute Books, 1999. Print.

"Atchison, Topeka \& Santa Fe Railroad Route Map from the 1891 Grain Dealers and Shippers Gazeteer." Map. Wikimedia Commons. n.p., 27 May 2006. Web. 9 June 2010.

Balderrama, Fransisco E. and Raymond Rodríguez. Decade of Betrayal: Mexican Repatriation in the 1930s. 2nd ed. Albuquerque: $U$ of New Mexico P, 2006. Print.

Besserer, José Federico. Topografías transnacionales: Hacía una geográfica de la vida transnacional. Mexico, D.F.: Universidad Autónoma Metropolitana, Unidad Ixtapalapa, División de Ciencias Sociales y Humanidades, 2004. Print.

Border Deaths Database. Arizona Daily Star, March 31, 2011. Web. 15 June 2010.

Cantú, Lionel, Jr. The Sexuality of Migration: Border Crossing and Mexican Immigrant Men. Ed. Nancy A. Naples and Salvador Vida Ortiz. New York: New York UP, 2009. Print.

Carrasco, Gilbert Paul. "Latinos in the United States: Invitation and Exile." Immigrants Out! The New Nativism and the Anti-Immigrant Impulse in the United States. Ed. Juan F. Perea. New York: New York UP, 1997. 190204. Print.

Chavez, Leo R. The Latino Threat: Constructing Immigrants, Citizens, and the Nation. Stanford: Stanford UP, 2008. Print.

Cornelius, Wayne. Introduction. Impacts of Border Enforcement on Mexican Immigration: A View from the Sending Communities. Ed. Wayne Cornelius and Jessica Lewis. Boulder: Lynne Rienner, 2006. 1-16. Print. 
Cornelius, Wayne, et al. Controlling Unauthorized Immigration from Mexico: The Failure of 'Prevention through Deterrence' and the Need for Comprehensive Reform. La Jolla: Center for Comparative Immigration Studies, U of California -San Diego, 2008. Web. 20 December 2008.

De Genova, Nicholas. "Race, Space, and the Reinvention of Latin America in Mexican Chicago." Latin American Perspectives 25.5 (1998): 87-116. Print.

---. Working the Boundaries: Race, Space, and "Illegality" in Mexican Chicago. Durham: Duke UP, 2005. Print.

De Genova, Nicholas and Ana Y. Ramos-Zayas. "Latino Racial Formations in the United States: An Introduction." Journal of Latin American Anthropology 9.2 (2003): 18-57. Print.

Doty, Roxanne Lynn. The Law into Their Own Hands: Immigration and the Politics of Exceptionalism. Tucson: U of Arizona P, 2009. Print.

Dreby, Joanna. Divided by Borders: Mexican Migrants and Their Children.

Berkeley: $U$ of California P, 2010. Print.

Fox, Jonathan. "Reframing Mexican Migration as a Multi-Ethnic Process." Latino Studies 4 (2006): 39-61. Print.

Gamio, Manuel. Forjando Patria. México, D.F.: Porrúa, 1916. Print.

---. Mexican Migration to the United States: A Study of Human Migration and Adjustment. Chicago: $U$ of Chicago $P, 1930$. Print.

Gómez, Laura. Manifest Destinies: The Making of the Mexican-American Race. New York: New York UP, 2007. Print.

González-López, Gloria. Erotic Journeys: Mexican Immigrants and Their Sex Lives. Berkeley: $U$ of California P, 2005. Print.

Gutiérrez, Diego and Hieronymus Cock. "Americae sive quartae orbis partis nova et exactissima descriptio." Map. Wikimedia Commons. n.p., 20 July 2008. Web. 3 June 2010.

Hsu, Spencer. "Work to Cease on 'Virtual Fence' Along U.S.-Mexico Border." Washington Post 16 March 2010. Web. 3 June 2010. 
---. "Immigration Raid Jars a Small Town: Critics Say Employers Should Be Targeted." Washington Post 18 May 2008. Web. 3 June 2010.

Jiménez, María. Humanitarian Crisis: Migrant Deaths at the U.S.-Mexico Border. San Diego: ACLU of San Diego and Imperial Counties; Mexico's National Commission of Human Rights, 2009. Web. 15 June 2010.

Lytle-Hérnandez, Kelly. Migra! A History of the U.S. Border Patrol. Berkeley: U of California P, 2010. Print.

Martin, Philip. Promise Unfulfilled: Unions, Immigration, and the Farm Workers. Ithaca: Cornell UP, 2003. Print.

McWilliams, Carey. 1935. Factories in the Field: The Story of Migratory Labor in California. Berkeley: U of California P, 2000. Print.

Menchaca, Martha. The Mexican Outsider: A Community History of Marginalization and Discrimination in California. Austin: $\mathrm{U}$ of Texas $\mathrm{P}$, 1995. Print.

---. Recovering History, Constructing Race: The Indian, Black and White Roots of Mexican Americans. Austin: U of Texas P, 2001. Print.

Meyer, Josh. "Drug Cartels Raise Stakes on Human Smuggling." Los Angeles Times 23 March 2009. Web. 3 June 2010.

Mignolo, Walter. Local Histories/Global Designs: Coloniality, Subaltern Knowledges, and Border Thinking. Princeton: Princeton UP, 2000. Print.

Ngai, Mai. "The Strange Career of the Illegal Alien: Immigration Restriction and Deportation Policy in the United States, 1921-1965." Law and History Review 21.1 (2003): 69-107. Print.

---. Impossible Subjects: Illegal Aliens and the Making of Modern America.

Princeton: Princeton UP, 2004. Print.

O'Sullivan, John. "Annexation." United States Magazine and Democratic Review 17.1 (1845): 5-10. Web. 16 June 2010.

Payan, Tony. The Three U.S.-Mexico Border Wars: Drugs, Immigration, and Homeland Security. Westport: Praeger Security International, 2006. Print. 
Pitt, Leonard. The Decline of the Californios: A Social History of SpanishSpeaking Californians, 1846-1990. Berkeley: U of California P, 1998. Print.

Quijano, Anibal. "Coloniality of Power and Eurocentrism in Latin America." International Sociology 15.2 (2000): 215-232. Print.

Richards, Leverette. "Agents Sweep Rising tide of Mexican Illegals South to the Border." The Oregonian [Portland, OR] 1 May 1953: 4M. Print.

Segura, Denise and Patricia Zavella. Introduction. Women and Migration in the U.S.-Mexico Borderlands. Ed. Denise Segura and Patricia Zavella. Durham: Duke UP, 2007. 1-34. Print.

Shear, Michael D. and Spencer S. Hsu. "President Obama to Send More National Guard Troops to U.S.-Mexico Border." Washington Post 26 May 2010. Web. 3 June 2010.

Stana, Richard M. Secure Border Initiative: Technology Deployment Delays Persist and the Impact of Border Fencing Has Not Been Assessed. Testimony Before the Subcommittee on Border, Maritime, and Global Counterterrorism, Committee on Homeland Security, House of Representatives. Washington, D.C.: U.S. Government Accountability Office, 2009. Web. 3 June 2010.

Stephen, Lynn. "Los Nuevos Desaparecidos: Immigration, Militarization, Death, and Disappearance on Mexico's Borders." Rethinking Security: Gender, Race, and

Militarization. Ed. Barbara Sutton, Sandra Morgen, and Julie Novkov. New Brunswick: Rutgers UP, 2008. 79-101. Print.

---. Transborder Lives: Indigenous Oaxacans in Mexico, California, and Oregon. Durham: Duke UP, 2007. Print.

---. Zapata Lives!: Histories and Cultural Politics in Southern Mexico. Berkeley: U of California P, 2002. Print. 
“Teozacoalco." Map. Relaciones Geográficas Collection. Nettie Lee Benson Latin American Collection at the University of Texas at Austin, n.d. Web. 3 June 2010.

Terraciano, Kevin. The Mixtecos of Colonial Mexico: Nudzahu History, Sixteenth through Eighteenth Centuries. Stanford: Stanford UP, 2001. Print.

Truett, Andrew. Fugitive Landscapes: The Forgotten History of the U.S.-Mexico Borderlands. New Haven: Yale UP, 2006. Print.

United States. Army. Ctr. of Military History. "Map 20 [The Mexican War, 18461847]." Map. American Military History. Washington D.C.: Army Historical Series, 1989. 167. Print.

Valenciana, Christine. "Unconstitutional Deportation of Mexican Americans during the 1930s: A Family History \& Oral History." Multicultural Education 13.3 (2006). Web. 15 June 2010.

Waldseemüller, Martin. "Closeup of the Martin Waldesmüller Map Showing South America and the Word 'AMERICA."' Map. Wikimedia Commons. n.p., 11 October 2006. Web. 3 June 2010.

Ward, Sir Adolphus Willam, et al. "Expansion of the United States." Map. The Cambridge Modern History Atlas. London: Cambridge University Press, 1912. Web. 9 June 2010.

Wilkinson, Tracy. "Cartels Smuggle U.S. Drug Money Back to Mexico in Cash, Study Finds." Los Angeles Times 3 June 2010. Web. 3 June 2010.

Wilson, Tamar Diana. Women's Migration Networks in Mexico and Beyond. Albuquerque: $U$ of New Mexico P, 2009. Print.

Zavella, Patricia. I'm Neither Here nor There: Mexicans' Quotidian Struggles with Migration and Poverty. Durham: Duke UP, 2011. Print.

Zinn, Howard. A People's History of the United States: 1492 to Present. New York: Harper, 2003. Print. 